\title{
Türk Sinemasında Kadının Temsil Sorununa Alternatif Bir Yöntemle Bakmak: Bechdel Test
}

\author{
Gülden Gevher Öz \\ Yaşar Üniversitesi Sosyal Bilimler Enstitüsü \\ guldenoz.81@hotmail.com \\ Orcid: 0000-0001-6568-2127 \\ Devrim Seçen \\ Yaşar Üniversitesi Sosyal Bilimler Enstitüsü \\ devrimsecen@gmail.com \\ Orcid: 0000-0002-8414-5332
}

Başvuru Tarihi: 17.09.2018

Yayına Kabul Tarihi: 27.11.2018

Yayınlanma Tarihi: 21.01.2019

\section{Öz}

Bu çalışmada uluslararası alanda pek çok makale ve teze konu olan "Bechdel Test" tanıtılmış ve testin feminist sinemaya katkısı ve eksik yönleri tartışmaya açılmıștır. Türkiye sinema araştırmalarında bugüne dek gündeme gelmemiş olan Bechdel Test'ten yola çıkılarak, Türk sinemasında kadının temsiline yeni bir pencereden bakılması amaçlanmıştır. Bu amaç doğrultusunda Türkiye Cumhuriyeti Kültür ve Turizm Bakanlığı'nın 2014 yılında yaptı̆̆ı halkoylamasıyla seçilmiş olan "En İyi 10 Türk Filmi"ne Bechdel Test uygulanmıștır. Bu filmlerde ortaya konulan kadına dair söylem, karşılaştırmalı bir değerlendirme yapmaya olanak sağlaması ve Bechdel Test verilerinin sağlamasının yapılması amacıyla, metin analizi yöntemi ile de incelenmiştir. Çalışma sonucunda, Bechdel Test'in ölçüm biçiminin sınırlılığından ötürü, testi geçen filmlerin tümünün feminist bakış açısına sahip olduğunun iddia edilemeyeceği ortaya konulmuştur. Bunun yanı sıra, 1985 yılında sinema ve kadın ilişkisine mizahi bir biçimde bakılarak ortaya çıkarılan Bechdel Test'in, sinemada kadın temsili konusunda yarattığı geniş farkındalığa da dikkat çekilmiştir. Yapılan çalışmada incelenen filmlerin pek çoğunun Bechdel Test'in oldukça basit üç koşulunu dahi tamamıyla sağlayamamış olduğunun görülmesi, Türk sinemasında kadının yokluğunun gözler önüne serilmesi bakımından önemlidir. Çalışmada testin Avrupa ülkelerindeki kullanımına ve bu testten hareketle yeni film ölçekleri de geliştirilebileceğine değinilerek, Türk sinemasında toplumsal cinsiyet temsili kriterlerinin oluşturulmasının gereği ortaya konulmuştur.

Anahtar Kelimeler: Bechdel Test, Sinemada Kadın, Sinemada Temsil, Feminist Sinema. 
Research Article

\title{
An Alternative Method to The Look At The Representation Problem of Women In Turkish Cinema: Bechdel Test
}

\author{
Gülden Gevher Öz \\ Yaşar University Institute of Social Sciences \\ guldenoz.81@hotmail.com \\ Orcid: 0000-0001-6568-2127 \\ Devrim Seçen \\ Yaşar University Institute of Social Sciences \\ devrimsecen@gmail.com \\ Orcid: 0000-0002-8414-5332
}

Date Received: 17.09 .2018

Date Accepted: 27.11.2018

Date Published: 21.01.2019

\begin{abstract}
In this study "Bechdel Test" has been introduced, which is subjected to many international articles and thesis and opened its contributions to the feminist cinema and missing aspects up for discussion. Based on the Bechdel Test, which hasn't been mentioned on the research about Turkish cinema up to the present, it is aimed that the representation of women is handled in a new perspective. In line with this purpose, Bechdel Test has been applied to "The Top 10 Turkish Film", chosen with a referandum in 2014, held by Ministry of Culture and Tourism of Turkish Republic. Discourse of women, seen in these films is examined by text analysis method in order to allow to make an mutual assessment and to check Bechdel Test data. As a result of the study, it is stated that: it isn't claim that all films, passed the test don't have a feminist perspective due to the restriction of Bechdel Test's measurement type. In addition to this, it is drawn attention to the wide awareness of women representation in cinema, created by Bechdel Test, which formed by approaching to the relation between cinema and women by a humorous perpective in 1985. It is important to see that many films, examined in the study haven't been met even three basic conditions of Bechdel Test in the sense that absense of women in Turkish cinema is displayed. In this study it is mentioned that this test is used in European countries and new film measures can be developed by using this test and also the necessity of creating social gender resentation criteria in Turkish cinema is presented.
\end{abstract}

Keywords: Bechdel Test, Woman İn Cinema, Representation İn Cinema, Feminist Cinema. 


\section{Giriş}

Sinemada kadın temsiliyle ilgili sorunların başında kadınların yeteri kadar gerçekçi temsil edilmemesi ve temsil biçimlerinin ideolojik ve ataerkil kültürün çıkarlarıyla uyumlu biçimde olması gelmektedir. Öztürk'e $(2000,69)$ göre, sinemada kadının temsili ataerkil ideolojiyle uyumludur. Sinemada kadına dair önemli sorunlardan biri, film metinlerinin erkek özneler üzerine kurulu olması; kadınların bu metinlerde ya hiç yer almaması ya da kadının kimliksiz ve metnin akışında işlevsiz birer aksesuar, birer nesne konumunda yer bulmasıdır. Popüler sinemada erkeklerin karar veren ve olayların gidişatına yön veren kişiler olarak temsil edildiğini belirten Yüksel $(2010,88)$, buna karşın kadınların tabi olan ve yönlendirilen kişiler şeklinde temsil edildiğini dile getirmiştir.

1960'lı yıllarda başlayan ikinci dalga feminizmin etkisiyle sinemada kadının yeri sorgulanmaya başlanmıştır. 1985 yılında bir karikatürde hicvedilen diyaloglar, takip eden yıllarda feminist alana pek çok katkı sağlayacak, sinemada kadının yokluğuna dikkat çekip bu konuda farkındalık uyandıracak bir sürece öncülük etmiştir. Alison Bechdel'in karikatüründen hareketle "Bechdel Test" olarak adlandırılan ve sinemada kadının yerini sorgulayan bir değerlendirme biçimi ortaya çıkmıştır.

Dünya genelinde çok sayıda tez ve makaleye konu olmuş olan Bechdel Test, oldukça basit bir analiz yöntemi önermektedir. Buna rağmen küresel bağlamda gişe yapmış filmlerin pek çoğu testi geçememiş ve bu da sinemada kadının yokluğunu çarpıcı biçimde ortaya koymuştur.

Bu çalıșmanın amacı, Türkiye sinema literatüründe daha önce üzerine yapılmış olan bir çalışmaya rastlanmayan Bechdel Test'i tanıtmak, testin eksik ve sınırlı yönlerini tartışmaya açmak ve buradan hareketle Türk sinemasında kadın temsilini yeni bir yöntemle incelemektir. Çalışmanın örneklemi, Kültür ve Turizm Bakanlığı tarafından 2014 yılında yapılan halk oylamasıyla belirlenen en iyi 100 Türk filminin en çok oy almış olan ilk on filmidir. Bu çalışmanın örneklemini oluşturan on film, geniş katılımlı bir halkoylamasıyla en yüksek oy alan filmlerden oluştuğu için, çalışma sadece filmin kadına bakışının değil; halkın da film metinlerinde ne tür bir söyleme ilgi gösterdiğinin anlaşılması açısından önemlidir.

\subsection{Bechdel Test}

Cinsiyetler arası ayrımcılığı tanımlamakta kullanılan Bechdel Test, Alison Bechdel'in 1985 tarihli "The Rule" adlı karikatürüne dayanmaktadır. Literatürde sıklıkla Bechdel Test adıyla geçiyor olsa da, çizere karikatürde işlenen konunun fikrini veren ve ilk karesinde de ismi geçen Liz Wallace'ten ötürü çeşitli kaynaklarda "Bechdel-Wallace Test" olarak da geçmektedir (Rughiniş ve diğerleri, 2016).

Karikatür, izleyeceği filmleri formülleştirmiş olduğu üç kurala göre seçen bir kadın karakteri içermektedir. Bu üç kural temelde üç sorudan oluşmaktadır:

- Filmde ismi bilinen en az iki kadın var mı?

- İsmi bilinen kadınlar birbirleri ile konuşuyor mu?

- Eğer konuşuyorlarsa, erkekler dişında bir konu hakkında mı konuşuyorlar?

Bechdel Test, kadınların erkekler dışında başka bir konu hakkında konuşmadıklarını ima ederek oldukça minimal bir temsil niteliği (Lindner ve Schulting, 2017, 2) gösteriyor olsa da, ticari amaç güdülerek üretilmiş olan filmlerdeki toplumsal cinsiyet rollerinin delili sayılabilir. Herhangi bir filmin testi geçememiş olması elbette bir 
rastlantı olarak görülebilir, ancak bir dizi filmin sistematik analizi film endüstrisinin cinsiyetçiliğini ortaya çıkarabilir (Garcia, Weber ve Garimella, 2014, 2).

Test, filmlerin yanı sıra bilgisayar oyunları, diziler ve çizgi roman analizleri için kullanılmaktadır (Keating ve Murphy, 2015:4). Bu açıdan değerlendirildiğinde test, kitle iletişim araçlarında üretilen ve yeniden üretilen toplumsal cinsiyet söylemini ortaya çıkarabilmek için uygulanabilen basit ve etkili bir araç olarak görülebilir. Sinemada kadın imgesinin temsiline ilişkin sorunlardan biri, kadınların nadiren güçlü liderler veya düşünürler olarak gösterilmesi, ancak sıklıkla klişeler olarak (Agarwal ve diğerleri, 2015, 830) beyaz perdede yer alması olarak belirtilmiștir. Bununla birlikte, filmlerde birden fazla kadının yer alıyor olması da klişe temsillerden vazgeçilmiş olunduğunun bir göstergesi değildir (Dutt, 2014, 10). Bechdel Test'in zamanla alternatif versiyonlarının geliștirilmesi, kadınların klişe temsillerine ait farklı yaklaşımlar olduğunu göstermektedir. Testin alternatif versiyonlarına örnek olarak ırksal Bechdel Test; siyahi iki kadının, yalnızca beyaz bir kadın hakkında konuşması üzerinedir. Annelik temalı Bechdel Test ise iki kadının, yalnızca çocuklar hakkında konuşması üzerine oluşturulmuş bir testtir.

Avrupa Konseyi film fonu Eurimages, 2014 yılında Bechdel Test'i değerlendirme kriterleri arasına almıştır. Bechdel Test, Eurimages'in 2018-2020 toplumsal cinsiyet eşitliği stratejisi planında da yer almaya devam etmektedir (Council of Europe, 2014).

İsveç sinemaları, Bechdel Test'i filmlerinin içeriğindeki toplumsal cinsiyet hakkında farklılık yaratmak adına kullanmakta, dahası test sonuçlarını şiddet ve çıplaklık gibi konular ile aynı şekilde derecelendirmektedir (Garcia, Weber ve Garimella, 2014, 2). Kang'ın (IndieWire, 2016) 2016 tarihli İsveç sinemalarında Bechdel Test'in kullanımı üzerine yapmış olduğu haberde, testin günümüz sineması üzerinde ne kadar etkili olduğu görülebilmektedir. 2013 yılında vizyona girmiş olan filmlerin yalnızca \%30'u testi geçebilmişken, bir sonraki yıl \%60'ı geçmiş, 2015'te ise bu rakam \%85'e ulaşmıştır. Testi geçen filmler iyi bir şekilde derecelendirilmekte ve okullarda da öğrenciler Bechdel Test hakkında eğitim almaktadır.

Bechdel Test adına açılmış bir internet sitesi de bulunmaktadır. Sitede 1892 yılından günümüze kadar olan tarihsel süreçte vizyona girmiş olan binlerce filmin teste tabi tutulmuş olduğu görülebilmektedir. Siteyi ziyaret eden kullanıcılar da filmlere not verebilmektedir. Buna göre; "İlk kriterde başarısız olan filmler 0 ile derecelendirilir, ilk kriteri geçen ancak ikinci kriterde başarısız olan filmlere 1 puan verilir, ikinci kriteri geçen ancak üçüncü kriterde başarısız olan filmlere 2 puan verilir, her üçünü geçen filmlere ise 3 puan verilir" (Agarwal ve diğerleri, 2015, 833). Bu çalışma kapsamına alınmış olan filmler de yukarıda yer alan puanlama sistemine tabi tutulacaktır.

\subsection{Bechdel Test İle Yapılan Çalışmalara Örnekler}

Bechdel Test, sinema filmlerine uygulanan ve filmlerdeki cinsiyetçi yaklaşımları ortaya çıkarmaya yarayan bir araç olsa da, filmlere ait senaryoları veya filmler üzerine yazılmış sosyal medya iletilerini analiz etmek için de kullanılmıştır.

Mičić (2015), çalışmasında dünya genelinde gişede büyük başarı sağlamış olan 20 filmdeki karakterleri Bechdel Test'e tabi tutmuştur. Çalıșmanın sonucunda, filmlerde erkeklerin hemcinsleriyle konuşma oranları, kadınların hemcinsleriyle konuşma oranından daha yüksek çıkmıștır. Kadınların sıklıkla aileyi ilgilendiren konular 
hakkında konuştuğu, nadiren iş arkadaşları ile etkileşimde bulunduğu belirtilmiştir. Görülebileceği üzere filmlere yönetilmiş üç soruluk bu minimal test, toplumsal cinsiyet rollerinin çözümlenebilmesi için önemli veriler sağlayabilmektedir.

Kapoor, Bhuptani ve Agneswaran'ın “The Bechdel in India: gendered depictions in contemporary Hindi cinema" (2017) adlı çalıșmaları, Bechdel Test'in klasik anlamda kullanılmasına bir örnektir. Yazarlar, 2007-2013 yılları arasında Hindistan'da vizyona girmiş olan on beş filmi Bechdel Test üzerinden değerlendirmiştir. Sonuç olarak filmlerin cinsiyetçi kalıpları desteklediği ortaya çıkmıştır. Bu çalışma aynı zamanda Bechdel Test'in herhangi bir ülkenin sinemasına uygulanabilirliğinin görülebilmesi bakımından önemlidir.

Bechdel Test, filmlerin senaryolarına da uygulanabilmektedir. Buna örnek olarak "Key Female Characters in Film Have More to Talk About Besides Men: Automating the Bechdel Test" (Agarwal ve diğerleri, 2015) adlı çalışma gösterilebilir. Çalışmada, Internet Movie Script adlı veri tabanından alınan toplamda 457 senaryo teste tabi tutulmuş ancak bu senaryoların yalnızca 191'i testi geçebilmiştir.

Garcia, Weber ve Garimella (2014), 470 filmin senaryosunu Bechdel Test'e tabi tutmuş, bununla birlikte filmlerin fragmanlarını sosyal medyada paylaşan kullanıcıların yorumlarını da analiz etmiştir. Sonuçlara göre, testi geçen filmlerin fragmanları diğerlerine nazaran daha az popülerdir ve kadın kullanıcılar sosyal medyada bu fragmanları erkek kullanıcılardan daha fazla paylaşmıştır. Görülebileceği üzere Bechdel Test, sinema filmlerine uygulanabildiği gibi, filmlerin senaryolarına da uygulanabilmektedir.

$\mathrm{Bu}$ çalışmanın yukarıda bahsi geçen incelemelerden farklı yönü, Bechdel Test'in sınırlılıklarının farkındalığıyla çift yöntemli olarak uygulanıyor olması, filmlerin Bechdel Test'in yanı sıra feminist metin analizi ile de okunacak olmasıdır. Bu sayede Bechdel Test sonuçlarının metinlerin ortaya koyduğu söylemle paralel olup olmadığı, dolayısıyla Bechdel Test'in geçerliliği de sınanmış olacaktır.

\section{Türk Sinemasında Kadın ve Erkek İmgesinin Temsili}

1960'lı yıllarda oluşmaya başlayan, "feminizmin ikinci dalgası" olarak adlandırılan dönemde yaşanılan kadın hareketleri, toplumu oluşturan bireylerin kitle iletişim araçlarında nasıl temsil edildiklerini ortaya çıkarmıştır. Feminist düşünürler, elbette görüşlerini tek bir kuramın çatısı altında toplamamıştır; ancak bu dönem geliştirilen farklı kuramlar edebiyat eserlerinde, sinema filmlerinde ve hatta sosyal bilimlerde kadinlara ve erkeklere atfedilen toplumsal cinsiyet rollerinin anlaşılmasında etkili olmuştur.

Feminizm ikinci dalgasının Türkiye’ye yansıması 1980'li yıllara denk gelmektedir. Bu dönem ülkede yaşanan toplumsal değişim sinemada da kendisini göstermiştir. 1980’li yıllara kadar olan süreçte, özellikle Yeşilçam olarak adlandırılan dönemde, etkileri günümüz Türk sinemasında da görülen melodram türündeki filmler üretilmeye başlanmıştır. Yeşilçam melodramları seyircileri en kısa yoldan etkilemeyi amaçlayan ve içerisinde olağanüstü durumlar ile basit bir şekilde karikatürize edilmiş karakterler barından filmlerdir (Özön, 1963, 80). Karakterlerinin iyi/kötü, zengin/fakir gibi zıtlıklar barındırdığı melodram türündeki filmlerin sonu evlilikle biter dolayısıyla döneminin ideolojik izlerini taşırlar (Agocuk, 2015, 569-570). Bu dönemde farklı sınıflara ait kadınların filmlerin merkezinde olduğu görülmektedir. 
Ancak kadınlar sıklıkla iyi eş, fedakâr anne, sessiz ve boyun eğen kişiler olarak temsil edilmiştir (Künüçen, 2001, 57). Yeşilçam dönemi filmlerinde erkekler, kadınların aksine vakitlerinin çoğunu evin dışında geçiren bireyler olarak filmlerde yer almıştır. Evin bakımını üstelenen baba, kahraman, yiğit, delikanlı gibi özellikleri bünyesinde barındıran erkekler aynı zamanda çapkınlık da yapmaktadır (Kotaman, 2009, 357). Ancak bu durum erkekler için oldukça olağan olarak resmedilmiş, dolayısıyla Türk sinemasında erkek egemenliğinin en üstün olduğu dönem Yeșilçam dönemi olmuştur. Öyle ki Kara Murat, Tarkan, Malkoçoğlu gibi erkek kahramanların yer aldığı çizgi romanlardan uyarlama filmler, neredeyse tamamen erkeklere ait bir dünyada geçmektedir (Demirtaş, 2004).

1980’li yıllar, kadın filmlerinin üretildiği dönem olarak anılmaktadır. Bu dönemde vizyona giren filmlerde kadınlar ön plana alınırken erkekler ikinci planda bırakılmıştır. Kendi bilincinin farkında ve kendine güvenen, özgür ve bağımsız kadınlar beyaz perdede yer almaya başlamıştır. Evlilik konusu artık gündemden düşmüştür, filmlerde dul kadınlar ana karakter olarak karşımıza çıkabilmektedir. Her ne kadar dul kadınlar filmlerin merkezinde yer alıyorsa da, filmlerde dul kadınların toplum tarafından hoş karşılanmadığı ve dul kalmış olan kadınların evlenmesi gerektiği vurgulanmıştır.

Kadın sineması olarak adlandırılan bu dönemde kadınlara ait sorunlar gerçekçi bir anlatım şekli ile beyaz perdeye aktarılmış olmasına rağmen geleneksel ataerkil söylemin izlerini görebilmek mümkündür. Bu dönemin filmleri için yapılan temel eleştirilerden biri, filmlerin kadınları konu etmesine rağmen eril bir dil ile anlatılıyor oluşudur (Bilge ve Sönmez, 2010; Doğan, 2013; Ekici, 2007). Erkeklerin ikinci planda kalması, ilerleyen zamanda erkek arkadaşlığının anlatılmaya başlanacağı filmlerin temelini oluşturmuştur.

Kadınlar 1990'lı yıllardan itibaren baskın karakterler olarak filmlerde yer almaya devam etmiştir, ancak bu dönemde vizyona giren olan filmlerde erkeklerin arkadaşlıklarına ait öykülerin anlatıldığı göze çarpmaktadır. Yeşilçam dönemi filmlerinde güçlü, korkusuz ve otoriter biçimde temsil edilen erkekler, 1990'lı yıllardan itibaren alışılagelmişin dışında rollerde beyaz perdede yerlerini almıştır. $\mathrm{Bu}$ dönemin filmlerinde erkekler güvensiz, güçsüz ve karamsar bireyler olarak temsil edilmiştir. Bunun yanında, 1990'lı yıllardaki erkek temsillerine ait belirgin olan diğer özellikler ise erkeklerin kadınlara önem veren ve ev işlerine de yardım eden kişiler olmasıdır. Erkekler bu döneme ait filmlerde geleneksel kalıpların dışında gibi gösteriliyor olsa da, hegemonik erkekliğe ait söylemlerin bu dönem filmlerinde yeniden üretildiği belirtilmiştir (Birtek, 2007; Kabadayı, 2004). 2000'li yıllara gelindiğinde ise gerçekçi temsillerin yanında geleneksel anlatı yapısının özelliklerini taşıyan temsillerin görülebilmesi mümkündür (Yalamaç, 2011).

Türk sinemasında Yeşilçam'dan günümüze kadar olan süreçte kadın ve erkek imgelerinin nasıl sunulduğu genel olarak değerlendirildiğinde; 1980'li yıllara kadar olan dönemde vizyona girmiş olan filmlerde erkek egemen söylemin doğrultusunda inşa edilmiş temsillerin yer aldığı görülür. Erkekler etken, kadınlar ise edilgendir. Evlilik ve aile kurumunun önemi vurgulanmış, kadınların da iyi birer eş ve anne olmaları üzerinde durulmuştur. Erkekler ise kadınların aksine özgür bireyler olarak temsil edilmiştir; evli olmalarına rağmen, vakitlerinin çoğunu dışarıda geçirebilmektedir. Kadın ve erkek arasındaki bu uçurum 1980'li yıllara gelindiğinde 
biraz da olsa eşitlenmiş gibi gözükmektedir. Kadınlar, çeşitli iş kollarında görev alabilmekte, dolayısıyla kendi ekonomik özgürlüklerine sahip olabilmektedir. Evlilik bir zorunluluk ve cinsellik ise artık bir tabu değildir. Ulusay'a $(2004,157)$ göre, Türkiye'deki kadın hareketine ve sinemada 1980'li yıllarda görülen kadın filmlerine bir tepki olarak, 1990'ların ikinci yarısından itibaren filmlerde erkekler arası dostluk teması sıkça kullanılmaya başlanmıştır. Günümüz Türk sinemasında gerçekçi bir anlatı yapısına sahip filmler ve karakter temsilleri görebilmek mümkünken, geleneksel toplumsal cinsiyet kodlarının yeniden üretildiği filmler de mevcuttur.

\section{Yöntem}

Bu çalışmada örneklem olarak, 2014 yılında TC. Kültür ve Turizm Bakanlığı tarafından yapılan halk oylamasıyla belirlenmiş olan en iyi on film seçilmiştir.

Türkiye Cumhuriyeti Kültür ve Turizm Bakanlığı tarafından, 2014 yılında, Türk sinemasının 100. yılı dolayısıyla 100'den fazla üniversite ve sivil toplum kuruluşunca belirlenen 300 film ilk kez internet sitesi üzerinden halk oylamasına sunulmuștur. Toplamda, 360 binden fazla tekil oyun kullanıldığı oylamayla, Türk sinema tarihindeki en geniş katılımlı çalışmalardan biri yapılmıştır (Kültür Bakanlığı, 2014). En iyi 100 filmin belirlendiği halk oylamasında en çok oy alan ilk on film örneklem olarak seçilmiştir.

Çalışma kapsamına alınmış olan filmler sırasıyla Susuz Yaz (Metin Erksan, 1963), Hababam Sınıfı (Ertem Ĕgilmez, 1975), Babam ve Oğlum (Çağan Irmak, 2005), Eşkıya (Yavuz Turgul, 1996), Canım Kardeşim (Ertem Eğilmez, 1973), Selvi Boylum Al Yazmalım (Atıf Yılmaz Batıbeki, 1977), Züğürt Ağa (Nesli Çölgeçen, 1985), Yol (Şerif Gören, 1981), Vizontele (Yllmaz Erdoğan, Ömer Faruk Sorak, 2000) ve Bir Zamanlar Anadolu'da (Nuri Bilge Ceylan, 2011) adlı filmlerdir.

Örneklem olarak adı geçen filmlerin seçilmesinin nedeni, filmlerin geniş bir katılımla belirlenmiş olması ve söz konusu halk oylamasının ilgili bakanlık tarafından yapılmasının güvenilirliğidir. Ayrıca söz konusu filmlerin farklı tür ve dönemlerden olmasının da çalışmaya kapsam bakımından katkı sağlayacağı düşünülmektedir. Şöyle ki, örneklem içerisinde 1960’lı yıllardan günümüze kadar olan süreçte her on yıllık dönemi temsil edecek en azından bir film bulunmaktadır.

Örneklem olarak belirlenen on filmde, daha önce açıklanmış olan Bechdel Test'in üç sorusunun cevabı aranacaktır. Bu sorular şunlardır:

- Filmlerde ismini bildiğimiz en az iki kadın karakter var mıdır?

- İsmi bilinen bu kadınlar birbirleriyle konuşmakta mıdır?

- Bu kadınlar birbirleriyle bir erkekten başka bir şey hakkında konuşmakta midir?

Bu soruların cevaplanmasıyla oluşturulacak olan tabloda filmlerin karşıladığı her kriter için bir puan verilerek filmler test ölçeğine göre değerlendirilecektir.

Daha önce de açılklandığı gibi bir filmin Bechdel Test'i geçmiş olması feminist ölçütlere uygunluğunun tam delili sayılamaz. Bunun yanı sıra, filmlerde kadının konumlandırılma biçimi, eril söylemin varlığı, filmlerdeki bakış düzenlemeleri ve sosyokültürel söylemler gibi pek çok etkenin de sorgulanması gerekir. Bu nedenle filmlere sadece Bechdel Test uygulamakla yetinilmemesi, ikinci bir yöntem olarak da filmlerin feminist bir perspektif ile metin analizine tabi tutulup eril söylemin varlı̆̆ 
ve filmlerde kadının konumu açısından değerlendirilmesi uygun bulunmuştur. Böylece filmlerdeki kadın temsilinin daha geniş bir kapsamda incelenmesi mümkün olacak ve Bechdel Test'in sonuçları ve metinsel analizin sonuçları karşılaştırılacaktır. Araştırmanın çift yöntemli olarak yapılması, Bechdel Test'in yapısı gereği yalnızca minimal sonuçlar vermesi nedeniyle, çalışmanın geçerliliğinin sağlanması için de faydalı görülmektedir.

Bu çalışmanın temel çıkış noktası, feminist eleştiriye katkıda bulunmuş olan Bechdel Test'i tanıtmak, testin sınırlı yönlerini tartışmak ve bu bağlamda Türk sinemasında kadının konumunu değerlendirmektir. Bu amaç doğrultusunda, halkoylamasıyla belirlenen Türk sinemasının en iyi on filmi incelenecektir. Örneklemde 1960 öncesi dönemden herhangi bir filmin yer almamış olması ve çalışmanın sadece on filmi kapsıyor olması bu çalışmanın sınırlılığıdır. Bunun yanı sıra, metin analizini on film üzerinden derinlemesine ve detaylı biçimde yapmanın bu çalışmanın temel amacına hizmet etmemesi nedeniyle, metinlere feminist bakış açısının ana hatlarıyla yaklaşılarak daha temel bir söylem üretilmeye çalışılacaktır.

\section{Bulgular}

\subsection{Filmlerin Bechdel Teste Göre Değerlendirilmesi}

Tablo 1: Bechdel Test'e tabi tutulmuş olan filmlerin puan durumları.

\begin{tabular}{|c|c|c|c|c|c|c|c|}
\hline 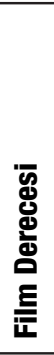 & Filmin Adı & $\begin{array}{l}\text { Film } \\
\text { Tarihi }\end{array}$ & Yönetmen & $\begin{array}{c}\text { İsmi } \\
\text { Bilinen } \\
\text { İki Kadın } \\
\text { Karakter } \\
\text { Var Mı? }\end{array}$ & $\begin{array}{l}\text { İsmi Bilinen } \\
\text { Kadın } \\
\text { Karakterler } \\
\text { Birbirleri ile } \\
\text { Konuşuyorlar } \\
\text { Mı? }\end{array}$ & $\begin{array}{c}\text { İsmi Bilinen } \\
\text { Kadınlar } \\
\text { Erkekler } \\
\text { Dışında } \\
\text { Başka } \\
\text { Bir Konu } \\
\text { Hakkında } \\
\text { Konuşuyorlar } \\
\text { Mı? }\end{array}$ & $\begin{array}{c}\text { Puan } \\
\text { Toplamı }\end{array}$ \\
\hline 1 & Susuz Yaz & 1963 & Metin Erksan & 1 & 1 & 0 & 2 \\
\hline 2 & Hababam Sınıfı & 1975 & Ertem Eğilmez & 0 & 0 & 0 & 0 \\
\hline 3 & Babam ve Oğlum & 2005 & Çağan Irmak & 1 & 1 & 1 & 3 \\
\hline 4 & Eşkıya & 1996 & Yavuz Turgul & 1 & 1 & 0 & 2 \\
\hline 5 & Canım Kardeşim & 1973 & Ertem Eğilmez & 0 & 0 & 0 & 0 \\
\hline 6 & $\begin{array}{l}\text { Selvi Boylum } \\
\text { Al Yazmalım }\end{array}$ & 1977 & Atıf Yılmaz & 1 & 0 & 0 & 1 \\
\hline 7 & Züğürt Ağa & 1985 & Nesli Çölgeçen & 1 & 0 & 0 & 1 \\
\hline 8 & Yol & 1981 & Şerif Gören & 1 & 0 & 0 & 1 \\
\hline 9 & Vizontele & 2000 & $\begin{array}{l}\text { Yılmaz Erdoğan, } \\
\text { Ömer Faruk Sorak }\end{array}$ & 1 & 1 & 1 & 3 \\
\hline 10 & $\begin{array}{l}\text { Bir Zamanlar } \\
\text { Anadolu'da }\end{array}$ & 2011 & Nuri Bilge Ceylan & 1 & 0 & 0 & 1 \\
\hline
\end{tabular}

Tablo 1'de görüldügü üzere, incelenen filmler arasından Babam ve Oğlum ile Vizontele filmleri testten tam puan almıştır. İncelenen on filmden ikisi sıfır puan almıştır. Sıfır puan alan Hababam Sınıfı ve Canım Kardeşim filmlerinde, isimleri bilinen en az iki kadın karakter dahi yer almamaktadır. Susuz Yaz ve Eşkıya filmleri, ismi bilinen iki kadının tek sahnelik konuşması ile testten iki puan almıştır. Diğer dört filmin tamamında, metinde ismi bilinen en az iki kadına yer verilmiş, ancak bu kadınlar birbiriyle herhangi bir konuda diyaloğa girmemiștir.

Babam ve Oğlum, Bechdel Test'in üç koşulunu da karşılayarak testten geçmiştir. Metinde ismi bilinen birden fazla kadın vardır. (Nuran, Sakine, Gülbeyaz, Birgül vs.) 
Bu kadınların sınırlı biçimde de olsa, erkekler haricindeki konularda konuştuğu sahneler mevcuttur. Örneğin bağda yaptıkları piknikte Nuran ve kardeşi Gülbeyaz, birbirleriyle atışarak bir müddet şakalașmıștır. Nuran, Gülbeyaz'ın sandalyede oturması nedeniyle ona takılırken, Gülbeyaz da kardeşinin cimri olduğunu ima eden sözler söyleyerek atışmayı sürdürmüştür. İsmi bilinen kadınlar arasında, bir erkeğin mevzu edilmesi dışında bir konuşma geçmesi nedeniyle film Bechdel Test'ten üç puan almıștır.

Vizontele filminde isimleri bilinen birden fazla kadın vardır. (Sıti Ana, Gülşen, Christine, Asiye, İsmihal vs.) Filmde isimleri bilinen iki kadının konuştuğu tek sahne vardır. Sıti Ana uyuklayan gelini Gülizar'a 'Gule, kalk karpuz ziftlen!' der. Gülizar, "Ana?" diyerek uyanınca Sıti Ana, "Zıkkımın kökü var, yer misin diyorum?" der. Gülizar "Yok ana istemem" diyerek cevap verir. Bu kısa diyalog vesilesiyle film, Bechdel Test'in üç koşulunu sağlayarak testi geçmiştir. Filmde isimleri bilinen en az iki kadın karakter olması, ismi bilinen iki kadının birbiriyle konuşması ve konuşmanın bir erkek hakkında olmaması nedeniyle film testten üç puan almıştır.

Susuz Yaz filmi, metnin bir sahnesinde görülen ve adı o sırada öğrenilen bir kadının, başroldeki kadın karakterle girdiği kısa diyalog sayesinde testten iki puan almıştır. Hasan'ın cezaevine girmesi ve Bahar'ın Osman'la aynı evde yaşamasının üzerine gelişen bu diyalogda, yolda yürüyen bir kadın, "Bahar sözümden alınmazsan sana bişey diyecem" der. Bahar, "Sözden alınecek ne var, söyle bakem" diye cevap verir. Kadın, "Osman bekâr; her ne kadar Hasan'ın ağası da olsa bir dam altında oturmanız kötü söz oluyor. 0 yüzden Osman'ı ever. Bul güzel bir kısmat, bitsin gitsin bu iş" der. Arkada yürüyen kadınlardan biri, "Nevruze doğru söylüyor. Osman'ı ever bahar" diyerek, diğer kadının söylediğini onaylar. Bu esnada Bahar'la konuşan kişinin adının Nevruze olduğu anlașılır. Bu karakter filmde ilk kez bu sahnede görülür ve metnin akışında başka bir rol üstlenmez. Sadece bu konuşma ve kadının isminin bu esnada öğreniliyor olması nedeniyle Susuz Yaz filmi Bechdel Test'in ilk iki koşulunu sağlayarak testten iki puan almıştır. Kadınların konuşmasının bir erkek üzerine olması nedeniyle film testin son koşulunu sağlayamamıştır.

Eşkıya filminde isimleri bilinen birden fazla kadın karakter vardır. (Ceran Ana, Keje, Emel vs.) Filmde erkekler arasındaki konuşma esnasında, mahalledeki kadınlardan birinin adının "Fatma” olduğu öğrenilir. Fatma'nın, Cumali'nin arkadaşı Cimbom’a mektup verdiği bir sahnede, "Sana, Sekine'den” demesiyle mahalledeki bir başka kadının adı öğrenilir. Filmde bu iki kadının birbiriyle kısa bir diyaloğa girdiği görülür. Fatma bir sahnede Sekine’ye Cumali için “Emel de ne buluyor bunda be? İtin teki!" der. Sekine "Hoş çocuk ama" diye cevap verir. İki kadın arasında geçen yaklaşık dört saniyelik bu diyalog nedeniyle film testten iki puan alabilmiştir. Kadınlar arasındaki konuşma bir erkek hakkında olduğu için, film Bechdel Test'in üçüncü koşulunu sağlayamamıştır.

Selvi Boylum Al Yazmalım filminde adı bilinen kadınlar Asya ve Dilek'tir. Filmde Asya'nın konuştuğu isimleri bilinmeyen kadınlar; Asya'nın annesi, komşusu ve Ali'nin karısıdır. Asya ve Dilek'in karşı karşıya geldikleri sahneler olsa da iki karakter birbiriyle konuşmaz. Film, isimleri bilinen kadın karakterler nedeniyle Bechdel Test'in ilk koşulunu sağlayarak testten bir puan almıştır.

Züğürt Ağa filminde, Zeliha, Kiraz ve Hatice, ismi bilinen kadın karakterlerdir. Filmde Zeliha'nın Kiraz'a seslendiği ve onu azarladığı sahneler mevcuttur. Ancak 
Kiraz, Zeliha'ya söz ile cevap vermez; sadece kendisine söylenileni yapar. Adı bilinen iki kadın karakterin yer alması nedeniyle, Züğürt Ağa filmi Bechdel Test'ten bir puan almıştır.

Yol filminde ismi bilinen kadınlar, Zine, Emine, Meral, Gülbahar ve Seyran'dır. Ancak bu karakterler film boyunca yan yana gelmezler. Filmde kadınlar arasında geçen tek diyalog, Zine ve adı bilinmeyen yengesi arasında geçer. Yol filminde ismi bilinen ikiden fazla kadın karakter olduğu için film Bechdel Test'ten bir puan almıştır.

Bir Zamanlar Anadolu'da filminde ismi bilinen iki kadın karakter vardır. Bu karakterlerden ilki; adı muhtardan öğrenilen ve elektrikler kesilince babasının lamba getirmesi için seslendiği Cemile'dir. Diğer kadın karakter Gülnaz'ın adı ise, eşinin cesedini teşhis etmesi için çağırıldığı sırada, savcıdan öğrenilir. Cemile filmde hiç konuşmazken, Gülnaz sadece 'evet' kelimesini söyler. Film, isimleri bilinen bu kadın karakterler nedeniyle, Bechdel Test'in ilk koşulunu sağlayarak testten bir puan almıştır.

Hababam Sınıfı filminde ismi bilinen tek kadın karakter Hafize Ana'dır. Bilgi yarışması sahnelerinde ismi bilinmeyen kadınlara rastlanmaktadır. Bu sahnelerde yarışmanın kadın sunucusu ve kız lisesi öğrencileri arasında, yarışma sorularının yöneltilmesi ve cevaplanması şeklinde oluşan bir diyalog yer almaktadır. Filmde kadınların karşılıklı konuşmalarının bulunduğu tek bölüm burasıdır. Ancak bu kadınların isimlerinin bilinmiyor olması ve filmde adı bilinen en az iki kadın bulunmaması nedeniyle, Hababam Sınıfı filmi Bechdel Test'in ilk koșulunu sağlayamamıştır. Bu nedenle film testten sıfır puan almıştır.

Canım Kardeșim filminde birden fazla kadın karakter bulunmasına rağmen, bu kadınların isimleri bilinmemektedir. Filmde konuşan ilk kadın Halit'in "teyze" diye seslendiği ev sahibidir. Tek sahnelik bu konuşmada kadın, Halit’ten üç gün içinde kirasını ödemesini ister. Filmde konuşan bir diğer kadın karakter ise Kahraman'ın öğretmenidir. Ancak onun da adı bilinmemektedir. "hoca hanım" olarak hitap edilen öğretmen kadın, ana karakterler olan erkeklerle diyaloğa girmektedir. İsmi bilinen en az iki kadın bulunmaması nedeniyle film Bechdel Test'in ilk koşulunu sağlayamamıştır. Bu nedenle Canım Kardeşim filmi Bechdel Test'ten sıfır puan almıștır.

\subsection{Filmlerin Feminist Perspektifle İncelenmesi}

\subsubsection{Susuz Yaz}

Metin, müşterek kullanımda olan köy suyunun, şahsi mülkiyet altına alınma çabası üzerine kuruludur. Metinde ilk olarak, köy suyunun kamusal kullanımını önleyip suyu özel mülkiyetine almak isteyen Osman'ın, köylülerle mücadelesi görülür. Bu

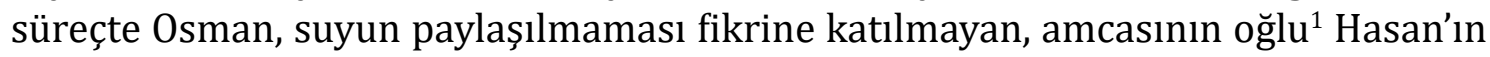
üzerindeki otoritesini arttırmaktadır. Osman'ın bir çatışma sırasında köylülerden birini vurması ve cinayeti üstlenmesi için Hasan'ı ikna etmesi üzerine; metin Osman'ın, Hasan'ın karısı Bahar'a sahip olma hırsı üzerine şekillenir. Metinde kadın, sahip olunabilecek bir nesne gibi konumlandırılmıştır.

Metin, kadının eril bakışa hizmet ettiği röntgenleme sahneleriyle örülmüştür. Kameranın alt açıyla Bahar'ın bacaklarına odaklandığı çok sayıda sahnenin yanı sıra, izleyicinin Osman'ın bakış açısıyla Bahar'ı gözetlemesinin sağlandığı pek çok sahne mevcuttur. Bu anlamda metin, Laura Mulvey'in (2014) dikizci haz söylemine örnek gösterilebilecek niteliktedir. 
Metinde Bahar, mahsulden sonra "posası çıkacağı" için bir an önce evlenilmesi gereken, emek ve işgücünden faydalanılacak bir nesnedir. Bahar, sevgilisi "Benim dediğim olur" dediği için evden kaçmayı derhal kabul eden, ev ve tarlada çalışıp duran ama yorulmayan, söylenmeyen, kocası öyle emrettiği için yalan ifade vererek onun suçsuz yere hapis yatmasına göz yuman, erkeğe tam olarak itaat eden biridir. Osman'ın tecavüzünden sonra da Bahar'ın Osman'ın ayaklarını yıkadığı ve erkeklere itaatini sürdürdüğü görülür. Bahar'ın başkaldırısı, Hasan'ın dönmesiyle Osman'a baltayla saldırdığı sahnede görülür ve Bahar vurularak bu teşebbüsün de, "kirletilmiş" olmanın da sembolik biçimde cezasını öder. Metinde kadına yönelik çok sayıda olumsuz söylem ve çok sayıda röntgenci bakış sahnesi mevcuttur. Metinde kadın görsel bir haz nesnesi olarak eril bakışın hizmetine sunulmuş, itaatkâr biçimde temsil edilmiş ve bir nevi meta olarak konumlandırılmıştır.

Metnin sonunda Osman'ın ölmesi ve cesedinin su kanalında sürüklenmesiyle, suyu mülkiyetine alma çabasının cezasını çektiği görülür. Bahar, vurulmasına rağmen ağır bir yara almamış ve hayatta kalmıştır. Hasan, yaralanmış olan Bahar'a, onu bir daha bırakmayacağını söyler. Ancak Hasan'ın sözünü tutabilmesi mümkün görünmemektedir. Çünkü tekrar hapse girecektir. Metinde Bahar'ın Osman'dan kurtuluşu da yine bir erkek sayesinde olmuştur.

\subsubsection{Hababam Sınıfı}

Erkeklerin dünyasını, erkekler üzerinden anlatan bu filmde ismi bilinen tek kadın karakter Hafize Ana'dır. Filmde okul içindeki yöneticilik, öğretmenlik, öğrencilik gibi tüm rol ve görevler erkeklere verilmesine rağmen; erkeklerin hizmet işlerinden yükümlü olan kiși kadındır. Hafize Ana filmde ütü yaparken, kahve servis ederken ve diğer hizmet işlerini yürütürken görülür. Adının yanına getirilen "ana" sıfatından da anlaşılabileceği gibi metinde yer bulan tek kadın, anaç özellikler taşımaktadır. Hafize Ana çalışkan, sevecen, merhametli ve kendini kalabalık erkek öğrenci grubunun annesi gibi gören ve onlar için her türlü fedakârlığı yapmaya hazır olan biridir. Okula yeni gelen Mahmut Hoca'nın kimi kimsesi olmadığını öğrendiğinde "Ben size de bakarım, kirlilerinizi falan yıkarım..." diyerek bu erkekler topluluğunun hizmet işlerini yürütmekteki adanmışlığını gösterir. Hafize Ana daha önce sözü edilen "fedakâr kadın" stereotipinin özelliklerine uymaktadır.

Metinde başka kadın figürlerle karşılaşma imkânı bulunan bölümler, bilgi yarışması sahneleridir. Burada da erkek yarışmacıların karşısına bir grup kız yarıșmacının çıktığı ve hile ile de olsa erkeklerin kızlara karşı galip geldiği görülmektedir.

\subsubsection{Babam ve Oğlum}

Metnin odak noktasını baba, oğul, torun zincirinde, erkekler arası ilişkiler oluşturmaktadır. Metnin söyleminde ataerkil aile yapısının özellikleri ve geleneksel cinsiyetçi rol dağılımları gözlenmektedir. Kadın temsilleri erkek egemen toplumun onayladığı normlar çerçevesinde kurulmuştur. İlk sahnelerde görülen hamile eş, kocası eve geç ve alkollü gelmesine rağmen birkaç sitemli söz dışında tepki vermez; sevecen ve anlayışlıdır. Deniz'in bakımını üstlenmiş olan Fatma Ana da, fedakâr ve anaç kadın özelliklerini tamamen göstermektedir. Nuran, oğlunun evden gitmesine sessiz kalıp, geçen yıllar içinde oğlu ve torununu görmeye gittiğini kocasından saklayan, kocasının otoritesini kabullenen bir eştir. Sakine ev işlerini yürütürken, evin gelini Hanife de çocuklarının bakımı ve kocasına bağlılık gibi normlar içerisinde cinsiyet rollerini yerine getirirken görülür. Gülbeyaz, kendisine miras 
kalan iki sıra ağacın Hüseyin Efendi'nin toprağına geçmesi yüzünden kardeşinin kocasıyla küsmüştür. Gülbeyaz'ın eşi vefat etmiştir ve yalnız bir kadın olduğu için, başında erkeği olan (dolayısıyla güç sahibi) tarafça hakkı gasp edilmiştir. Nuran da kız kardeşine her sene mahsulün parasını kendisine yolladıklarını söylerken bu haksızlığı kabul etmiștir. Maddi değeri az da olsa haksızlığa uğramış olan, yalnız olan, "dul" kadındır. Başında onun haklarını (ağaçlarını, toprağını vb.) savunacak bir kocası yoktur. Birgül, kavuşamadığı sevdiğinin ardından perișan olup, sonradan kaderini kabullenen biridir. Oğluna "Sadık" ismi vermek isteyip, kocası anlar diye bunu ona söyleyememesi ve hastane ziyaretinde Sadık'ı hiç unutmadığını itiraf etmesinden anlaşıldığı gibi, sevmese de kocasını, anneliği, ev işlerini ve kendisine dayatılan hayatı dirençsiz kabul eden biridir.

Nuran'ın oğlunun eve dönmesiyle otoriteye karşı geç de olsa karşı bir duruş sergileme kararlılığında olduğu söylenebilir. Oğluna kocası için "Az bekle sen, tükürügümle boğarım ben onu ya, az bir zaman geçsin..." demesi ve kocasına "O giderse ben de giderim, şart olsun boşarım seni!" diyerek yemin etmesi, kadının otoriteye karşı başkaldırıya hazır olduğunu göstermektedir. Ancak metnin akışıyla bu direnişin sürmesine gerek kalmaz ve kadın ve erkek eski rollerini sürdürerek yaşamlarına devam eder.

Genel olarak metin, hâkim eril söylemin kadın temsillerine uygun biçimde inşa edilmiştir.

\subsubsection{Eşkıya}

Metin, erkekler arası ilişkiler üzerine kurulmuştur. Metinde kadının temsil biçimi oldukça sorunludur. Cumali'nin söz ettiği, babasını aldatan üvey annesi; Cumali'nin aşkından faydalanıp abisi olarak tanıttığı sevgilisiyle kaçan Emel; Cumali'nin çocukluğunda, kocasının yeğenini taciz ettiğini fark edip buna göz yuman halası, kadın karakterlerin nasıl kötücül tasvir edildiğinin örnekleridir.

Metinde masum olarak simgelenen Keje ise, aşkı için 35 sene suskun kalmayı göze almış bir karakterdir. Baran, Keje için hapse girmiş, Berfo ise Keje için cehenneme gitmeyi göze almıştır. Baran’ın, Berfo'nun, Cumali'nin babasının ve Cumali'nin hayatlarındaki kırılma hep kadınlar nedeniyle olmuştur. Erkeğin mahvolmasına sebep kadındır.

Keje'nin sessizliğini bir direniş biçimi olarak okumak da mümkündür. Ancak yine de bu fazlasıyla edilgen, teslimiyetçi ve kaderini kabullenmiş suskunluk, kadının biçareliğinin bir teyididir.

\subsubsection{Canım Kardeşim}

Metinde çok az sayıda kadın yer almaktadır. Metnin seyrinde etkisi bulunan tek kadın, Kahraman'ın öğretmenidir. Murat ve Halit'e çocukla ilgilenilmesi gerektiğini söyleyen ve çocuğun vücudundaki kaşıntı ve lekeleri ilk fark eden de odur. Öğretmen kadın bilge, anaç, ilgili, duygusal biri olarak temsil edilmiştir.

Metin erkekler arası ilişkiler ekseninde, erkeklerin yaşadığı yoksulluk, çaresizlik gibi güçlüklere odaklanmıştır. Metinde karakterlerin hayatında iki yoksunluk dikkat çeker. Birincisi paradır. Ev eşyaları, kıyafetler, yenilen yemekler ve diğer unsurlar metin boyunca baskın bir yoksulluk yaşandığını vurgular. Bir diğer yoksun olunan şey de kadındır. Dile getirilmese de, ataerkil sistemin evi çekip çevirme, temizlik 
yapma, yemek pişirme, çocuklarının bakımını üstlenme gibi görevler atfettiği kadının yokluğu, izleyicinin şefkatinin erkeğe yönelmesini sağlamıștır. Buradan hareketle metnin kadınlara erkeklerin hayatındaki görev ve sorumluluklarının önemini hatırlatma işlevi de bulunmaktadır.

\subsubsection{Selvi Boylum AI Yazmalım}

Metin temel olarak ailesinin sözünü dinlemeyip, aşkı seçen kadının başına gelen olumsuz olaylara odaklanmış ve bu sayede ataerkil toplum normlarına uyarak, "uslu kız" olmanın önemi vurgulanmıştır. Metnin dikkat çeken bir noktası, Asya'nın babası olduğunun bilinmesine rağmen filmde hiç görünmüyor olması ve Asya'nın hayatındaki baskı unsuru olarak anne figürünün ön plana çıkmasıdır. Bu da ataerkil kültür normlarının yaşatılmasında erkekler kadar kadınların da büyük etkisinin olduğunu göstermektedir.

Metinde köylü kızı Asya'ya olumlu özellikler yüklenirken, meslek sahibi ve şehirli kadın Dilek, ahlaki bakımdan zayıf biri olarak temsil edilmiştir.

Metinde İlyas'ın Dilek'le beraber yaşamaya başlayıp Asya'yı terk etmesine sebep olan olay, Asya'nın İlyas'ın müdürüyle görüșmeye gidip dedikoduya mahal vermesi ve uygunsuz biçimde erkek işine karışmasıdır. İlyas bu sırada Asya'ya tokat atar ve kırılma noktası da denilebilecek olan Dilek'e gitme kararını, kadının bu kusurlu davranışından sonra verir. Erkeği hatalı davranışa yönlendiren süreçte kadının kusurlu biçimde temsil edilmesi, erkeğin yanlışları için hafifletici bir sebep olarak kullanılmıştır.

Metnin sonunda Asya iki erkek arasında seçim yapmak zorunda bırakılır. Kadının tek çıkış yolu ve hayatta kalma şansı, yanında bir erkeğin olmasına bağlıdır. Asya sevdiği erkekle genç yaşta yaşadığı "uygunsuz" beraberliğin bedelini metin boyunca ödemiştir ve son fedakârlığını da çocuğu için ve minnet duygularıyla yaparak, bedel ödemeye devam eder. Kentli ve "hafif" kadını tercih eden İlyas da çocuğunu kaybetmekle bir bedel öder ve metin, sistem içinde kalmanın önemini her iki cinsiyete de tekrar hatırlatır.

\subsubsection{Züğürt Ağa}

Metinde ataerkil sistemde kadının dövülmesi, üzerine kuma getirilmesi, başlık parası karşılığında mal gibi satılması, kız çocuklarının değersiz görülmesi gibi pek çok konuya dikkat çekilerek bir tür sistem eleştirisi yapıldığı söylenebilir. Metinde ağanın eşi Zeliha, eşini çekinmeden eleştirebilen biridir; cinsel taleplerini dile getirebilecek bir yapıdadır ve silik bir karaktere sahip değildir. Zeliha'nın diğer kadınlardan farklı bu özellikleri ağa kızı olması nedeniyle, yani yine arkasındaki başka bir güçlü erkek figür dolayısıyladır. Buna rağmen Zeliha da ev işlerinden sorumludur, kocasının seçimlerinde söz hakkına sahip değildir hatta ağanın açtığı bakkal dükkânında eşinden dayak yer.

Ağanın annesi ise yaşlı eşinin kuma getirme isteğine "Sen gitme herif, ben kumaya razıyam; sen gitme!” diyerek rıza gösterir. Çünkü erkeğin mutluluğu ve salimliği, onu seven bir eş için her şeyden önemli ve üstündür.

Kiraz ise oldukça teslimiyetçi bir karakter olarak okunmaktadır. Yanındaki kadınlardan yediği dayaklara rağmen sakin halini sürdürür. Ağanın kendisine talibiyle evlenmek isteyip istemediğini sorduğu sahnede; ağanın başlık parasına 
ihtiyacı varsa, istemediği biriyle evlenmeyi bir fedakârlık olarak kabul edebileceği görülür. Metinde baskın olan kadın olumsuz biçimde temsil edilmiş ve sonunda metnin içindeki varlığına son verilmiştir. Böylece teslimiyetçi ve erkeğe fazlasıyla adanmış özellikleriyle olumlanan “iyi kadın”la erkeğin kavuşması mümkün olmuştur. "Her kızın gönlünde bir ağaya varmak vardır" diyen Kiraz, erkeğe itaatini ve ataerkil sisteme bağlılığını sürdürmüștür.

\subsubsection{Yol}

Metin erkek özneler üzerine kuruludur; erkek öznelerin hikâyelerine odaklanarak, kadınları anlatının dramatikleşmesinde birer nesne olarak kullanan bir yapıdadır. Metinde kadının ataerkil sistem karşısındaki aczi, zavallılığı, kimliksizleștirilmesi ve ezilmişliği ortaya konulduğu için, cinsiyetçi açıdan sistem eleștirisi yapan bir film olarak okunabilir.

Ancak metin içinde kadının erkeğin namusunun taşıyıcısı olduğu, namusa sürülebilecek lekenin failinin sadece kadın olabileceği, bunu yapan kadının insanlık dışı bir yaşama maruz bırakılmasının, işkence görmesinin, öldürülmesinin gereğine dair pek çok diyalogla karşılaşmak mümkündür. İhanete uğrayan erkek, onurlu, iyi kalpli, sevecen bir eş olarak betimlenmiştir ve cezaevinde kendisini bekleyeceğine söz veren karısı tarafından haksızlığa uğramış olduğu duygusu yaratılmıştır. Kadının Soğukoluk'ta bir genelevde bulunduğunun söylenmesi de, ihanet eden kadının sonunun "kötü yol" olacağı mesajını içermektedir.

Emine, çocuklarının babasıyla beraber olmaması yönünde baba ve ağabey baskısı görmüș, Meral, kendisine giyim, konuşma, oturma kalkma konusunda türlü yasaklar koyup hayatını ipotek altına alan adama hayranlıkla "Ne güzel konuşuyorsun, mahpusta mı öğrendin bunları?” diyerek tam itaat göstermiştir. Zine, suçlu olduğunu düşünmektedir ve kendi de ölümü hak ettiğine inanıp katledilmesinin bir mecburiyet, gereklilik olduğunu düşünür; kendini savunmaz, ihanetine bir açıklama getirmez. "Kendim ettim kendim buldum" der.

Metnin sonunda ataerkil sistemin kurallarına uymayan kadınlar Emine ve Zine ölümle cezalandırılır. Zine'nin donarak ölmesine sebep olan Seyit Ali, sonradan pişmanlık göstermesi ve acı çekip ağlaması gibi sahnelerde şefkate muhtaç konumunu korur. Hatta Zine'nin donmaması için oğlu ve kocası tarafından geç kalınmış kurtarma çabasındaki kırbaçlama da, sembolik olarak kötüyü cezalandırma ve bir duygusal boşalma aracıdır. Köylü kızı Gülizar sevdiği adama kavuşamamakla, eşini kaybeden yenge de kayınbiraderiyle evlendirilmekle farklı şekillerde cezalandırılır. Sistem, kadına mutlu olma, ayakta kalma, kaderine karşı gelme şansı tanımamaktadır.

\subsubsection{Vizontele}

Metinde kadınlar ataerkil toplum normlarına paralel biçimde sunulmuştur. Gülșen, üstüne kuma getirmeyi düşünen kocasına, "Sen başka bir kadın almayı düşündüğüne göre, bunda benim de bir kabahatim olabilir" der. Uzun zamandır kendisine bakmadığını söyleyen Gülşen, kocasının başka bir kadın arayışının sorumluluğunu üstlenir. Asiye'nin babası eşi istediği için değil, fotoğrafçıdaki yeni saatle poz vermek için fotoğraf çekilmeyi kabul etmiştir. Simo, Emin'e altı çocuk sahibi eșinden bahsederken "Erkek doğuramıyor" der ve kapıdan çıkarken karısını itip kakar. Diğerlerine nispeten daha güçlü bir kadın karakter olarak görülen Sıti televizyonu 
sakladığında geçmiş mesleği öğretmenlik olan belediye başkanı eşi "Elimden bir kaza çlkacak!" diye söylenir. Asiye sevmediği bir adamla evlendirilmeyi kabullenir. Metinde uzun bir sabır döneminden sonra da olsa, kaderini kabullenmeyip direnç gösteren tek kişi Gülizar'dır. Onun da çocuklarıyla beraber gideceği yer, aynı toplumsal rol ve yükümlülükleri sürdüreceği baba evidir.

Metinde özellikle dikkat çeken nokta ise kırsalda yaşayan kadınların toplumsal normlara uygun biçimde çizilmiş olması ve TRT ekibinde görevli olan kentli kadın öznenin ahlaki değerleri zayıf, görünümüne çok önem veren, aşırı dırdırcı özelliklerle oldukça olumsuz olarak sunulmasıdır. Metinde kentli ve meslek sahibi kadına karşı, kırsaldaki boyun eğmiş kadın yüceltilmiştir.

\subsubsection{Bir Zamanlar Anadolu'da}

Metin erkekler arasında geçen bir hikâye üzerine kurulmuştur. Erkek özneler üzerine işleyen metnin içinde, tek bir söz etmeyen muhtarın kızı Cemile ve filmin sonlarında görülen, kocasını teşhis ederken ağzından zoraki bir "Evet” çıkan Gülnaz yer almaktadır. Cemile çay servisi yaparken tüm erkekleri güzelliğiyle büyüler. O’nun filmdeki görevi, karanlık bir ortamda elinde tuttuğu lambayla, salt "güzelliği" sayesinde erkeklerin hülyalara dalmasına aracılık etmektir. Cemile, güzelliğinden başka kimliği olmayan biridir ve metnin akışında işlevi olan bir özne olmaktan uzaktır. Muhtarın evinde erkekler "Eline sağlık yenge" dediklerinde bile kamera muhtarın karısına dönmez. Kadının oradaki önemsiz varlığı bu küçük diyalogla hissettirilir sadece.

Komiser Naci'nin “Nerede bir karışıklık görürsen kadına bakacaksın. Orada mutlaka bir kadın meselesi vardır" sözü de eril söylemin kadına bakıșının teyidi gibidir. Savcı, doktorla sohbetinde, karısının intiharına sebep olduğunun geç farkındalığına ulaşınca "Kadınlar bazen çok acımasız olabiliyor doktor ya, çok!" demiştir. Erkek için karısını aldatması önemsiz bir şeydir. Kadının bunu önemsemeyip çabucak unutması ise olağan olandır.

Metnin temel konusu olan cinayette ise maktule diri diri gömüldüğü için şefkat gösterilmesi sağlanır. Katil ise doktorun merhametini kazandığı sahneler ve sonradan ortaya çıkan çocuğun kendisine ait olması, oğlu tarafından taşlanması, yolda giderken çok ağladığının anlatılması gibi detaylarla şefkate muhtaç konuma getirilir. Ancak ölen adamın eşi Gülnaz'a hiçbir sahnede şefkat yönlendirilmez. İzleyiciye karakterin derinliğine dair detaylar verilmez. Kadın eşini kandıran ve başka birinin çocuğunun ondan olduğuna inandıran, nihayetinde de bu cinayete sebebiyet verendir.

\section{Sonuç ve Değerlendirme:}

Türk sinemasının en iyileri olarak seçilmiş on filmin ikisinin Bechdel Test'ten sıfır puan alması; filmlerin dördünde ismi olan iki kadın olmasına rağmen bu kadınların karşılıklı diyaloglarının bulunmaması; testten iki ve üç puan alan filmlerin de bu skora ya tek sahneyle, ya da sınırlı sayıda kadınlar arası diyalogla ulaşması, Türk sinemasında kadının yokluğunun teyidi olarak görülebilir.

Bechdel Test'ten tam puan alarak testi geçmeyi başaran Babam ve Oğlum ve Vizontele filmlerinde kadına yönelik söylemin, ataerkil kültürel normlara dayalı olarak kurulduğu gözlenmiştir. Bu durum bir filmin Bechdel Test'i geçmesinin, feminist söylemle paralel bir metne sahip olduğunun göstergesi olamayacağını doğrulamaktadır. Testten iki puan alan Eşkıya filminde suskun kadının yüceltilmesi ve oluşturulan kötücül kadın söylemi, iki puan alan diğer film olan Susuz Yaz'ın kadını 
metalaştıran ve eril bakışın hizmetine sunan dili; test puanın yükselmesinin, filmin kadının konumlandırılma biçimine etkisi olmayacağının göstergesidir.

Yapılan çalışma ile Bechdel Test'in sadece kadının metin içindeki varlığını sınayan kısıtlı bir ölçme aracı olduğu teyit edilmiştir. Ancak yine de, testi geçemeyen filmlerin geçebilenler karşısındaki yüksek oranı düşünüldügünde, testin bilinirliğinin ve kullanımının artmasının, sinemada kadın sorununa dair önemli bir farkındalık yaratacağı düşünülmektedir.

İncelenen filmlerin tamamında, kadına ataerkil kültürel normlarla bakıldığı ya da kadına dair sorunlu bir dil kullanıldığı görülmüştür. Bu filmlerin, halk tarafından, geniş bir katılımla Türk sinemasının en iyileri olarak seçilmiş olması da izleyicinin kadının temsilindeki bu sorunlu yaklaşımı kanıksamış olduğunun bir göstergesidir.

Bechdel Test'in kullanıldığı günden bu yana İsveç sinemasında yaşanan olumlu değişime bakılarak, Türkiye'de de sinemada toplumsal cinsiyet eşitliğini sağlayacak bir takım ölçütlerin belirlenmesinin olumlu etkileri olacağı söylenebilir. Filmlere verilen teşviklerde bu ölçütlere uyulmasının, ulusal kanalların film yayınlama kriterleri belirlemesinin, akademisyenler, sinema sektöründen katılımcılar, yapımcı, dağıtımcı ve sinema salonlarının eş güdümlü çalışmalarıyla ortak bazı toplumsal cinsiyet normları oluşturulmasının sinemamıza büyük katkılar sağlayacağı düşünülmektedir. Sinema, toplumsal bilinçaltını şekillendirmede en önemli araçlardan biridir. Bechdel Test gibi basit bir ölçüm aracının Eurimages ve İskandinav ülkelerince ilgi görmesi, testin sağladığı farkındalık ile sinemada kadının konumunun üzerinde dikkatle durulan bir mesele haline gelmesi, Türk sineması için de örnek alınması gereken bir durumdur.

\section{Notlar}

${ }^{1}$ Literatürde daha önce yapılmış olan çalışmalarda (Coş, 1975, 30; Güngör, 2014, 92; Kayalı, 2004, 78; Özgüç, 1993, 136; Sim, 2009, 185; Sönmez, 2010, 129; Uslu, 2007, 60 ) Hasan ve 0sman'dan kardeş olarak bahsedildiği görülmektedir. Filmin uyarlandığı Necati Cumalı'nın aynı adlı eserinde de bu iki karakter (büyüğün adı Hasan, küçüğününki Osman olmak suretiyle) kardeştir (Bayram, 2018, 165). Film metninde köylüler Osman ve Hasan'ın aynı kandan olduğunu söyler. Osman, Bahar’a artık onların ailesinden olduğunu söyler. Hasan ve Osman'ın soyadları aynıdır ve bu iki erkek aynı evde yaşar. Osman'ın Hasan'a "Ben dediğimi yaparım gardaşım!”, "Hiç olmazsa söze karışma, gardaşlığını böylelikle göster" ve "Topraklarımız kurtuldu gardaşım!” dediği sahneler mevcuttur. Hasan da Osman'a "ağa" diye hitap eder ve "büyüğümsün" der. Ancak Hasan'ın cezaevinden Osman'a yazdığı mektup, dış ses ile Hasan'ın, “Emmioğlun Hasan” demesiyle başlar. Gardaş ve ağa kelimelerinin, aralarında yaş farkı olan yakın akrabalar tarafından birbirlerine hitaben kullanılabileceği ancak kardeşin ağabeyine kendisini "emmioğlun" diye tanıtamayacağı düşünülmektedir. Hasan'ın mektupta “Emmioğlun Hasan” demesi nedeniyle, Hasan ve Osman'ın amca çocukları olarak okunması tercih edilmiştir.

\section{Kaynakça}

Agarwal, A., Zheng, J., Kamath, S.V., Balasubramanian, S., ve Dey, S.A. (2015). Key Female Characters in Film Have More to Talk About Besides Men: Automating the Bechdel Test. Human Language Technologies: The 2015 Annual Conference of the North American Chapter of the ACL, s.830, 833.

Agocuk, P. (2015). Türk Sineması'nda Melodram: “Seven Ne Yapmaz” Filmi Üzerinden Yeşilçam Sineması'nda Melodramın Kodlarının Çözümlenmesi. Uluslararası Sosyal Araştırmalar Dergisi, 8, (40). s. 569-570. 
Bayram, S. (2018). Necati Cumalı'nın Susuz Yaz Adlı Hikâyesinde Yapı ve İzlek. The Journal of Social Science. 2, (4), s.165.

Bilge, D., Sönmez, S. (2010). 1980'li Yıllarda Türk Sinemasında "Dul” Kadın İmgesi. Çoban Döşkaya, F. (Ed.). 21. Yüzyılın Eşiğinde Kadınlar, Değişim ve Güçlenme, Uluslararası Multidisipliner Kadın Kongresi (13-16 Ekim 2009) Bildiri Kitabı. Cilt: 4, s.464-473. İzmir, Dokuz Eylül Üniversitesi Fen Edebiyat Fakültesi.

Birtek, B, F. (2007). Toplumsal Cinsiyet Açısından Sosyal Değişimlerin Türk Sinemasında Erkek Kimliklerine Yansıması: Koca Rolü (1980-2000 Yılları Arası). Marmara Üniversitesi Sosyal Bilimler Enstitüsü İletişim Bilimleri Anabilim Dalı. Yayınlanmamış Yüksek Lisans Tezi, Marmara Üniversitesi, İstanbul.

Council of Europe. (2014). Eurimages Strategy - For Gender Equality in the Europen Film Industry. Erişim: 25 Ağustos 2018. https://rm.coe.int/eurimagesstrategy-for-gender-euqality-in-the-european-film-industry/168073286d

Çoş, N. (1975). Hangi Toplumsal Gerçeklik? “Susuz Yaz”. Yedinci Sanat, (24), s.30.

Demirtaş, H. (2004). Türk Sinemasında 1960-1980 Ylllarl Arasında Çizgi Roman Uyarlaması Fantastik Filmlerde Erkek Kahraman Temsili. Anadolu Üniversitesi Sosyal Bilimler Enstitüsü Sinema Televizyon Anabilim Dalı. Yayınlanmamış Yüksek Lisans Tezi. Eskişehir.

Doğan, H. (2013). Türk Sinemasında 1980'li Yıllar Ve “Dulluk" Teması Etrafında Üretilen Geleneksel Cinsiyet Rolleri. Folklor/edebiyat, 19, (76).

Dutt, R. (2014). Behind the Curtain: Women's Representations in Contemporary Hollywood. MEDIA@LSE MSc Dissertation Series. s.10. Erişim: 27 Ağustos 2018, http://www.lse.ac.uk/media@lse/research/mediaWorkingPapers/ ElectronicMScDissertationSeries.aspx

Ekici, A. (2007). 1980-1990 Arası Türk Sinemasında Kentsel Ailede Kadının Konumu. Ankara Üniversitesi Sosyal Bilimler Enstitüsü Radyo Televizyon ve Sinema Anabilim Dalı. Yayınlanmamış Yüksek Lisans Tezi, Ankara.

Garcia, D., Weber, I., Garimella, V, R, K. (2014). Gender Asymmetriees in Reality and Fiction: The Bechdel Test of Social Media. ICWSM'14,s.2. Erişim: 27 Ağustos 2018, https://arxiv.org/pdf/1404.0163v1.pdf

Güngör, A, C. (2014). Auteur Kuramı ve Metin Erksan Sineması. The Journal of Academic Social Science Studies, (30), s. 92.

Kabadayı, L. (2004). Toplumsal Cinsiyet ve Film '90'lı Yillarda ABD-İspanya-Hong Kong ve Türk Sinemasinda Üretilen Filmlerde Toplumsal Cinsiyet Olgusunun Feminist Yaklaşımla İncelenmesi. Ege Üniversitesi Sosyal Bilimler Enstitüsü Radyo Televizyon Anabilim Dalı. Yayınlanmamış Doktora Tezi, İzmir.

Kang, I. (2016). What Happened After Swedish Theaters Introduced a Bechdel Rating for Its Movies? Erişim: 25 Ağustos 2018, https://www.indiewire. com/2016/02/what-happened-after-swedish-theaters-introduced-abechdel-rating-for-its-movies-204746/

Kapoor, H., Bhuptani, P, H., Agneswaran, A. (2017). The Bechdel in India: gendered depictions in contemporary Hindi cinema. Journal of Gender Studies, 26, (2). Erişim 20 Ağustos 2017, https://doi.org/10.1080/09589236.2015.1102128 
Kayalı, K. (2004). Metin Erksan Sinemasını Okumayı Denemek. Ankara, Dost Kitabevi Yayınları, s.78.

Keating, A., Murphy, J. (2015). Women and Media in the Twenty-First Century. Alphaville: Journal of Film and Screen Media, 10, s. 4.

Kotaman, A. (2009). Zihinsel Koleksiyonlar: Yeșilçam'dan Beyazcama. Kebikeç, Insan Bilimleri İçin Kaynak Araştırma Dergisi, (27), s.351-366.

Kültür ve Turizm Bakanlığı. (2014). Türkiye En İyi 100 Türk Filmini Seçiyor (Haziran 2014). Erişim: 25 Ağustos 2018, http://basin.kulturturizm.gov.tr/ TR,100574/turkiye-en-iyi-100-turk-filmini-seciyor.html

Kültür ve Turizm Bakanlığı. (2014). Türk Sinemasının 100'üncü Yılında Halk, “Susuz Yaz” Dedi (Eylül 2014). Erişim: 25 Ağustos 2018, http://basin.kulturturizm. gov.tr/TR,121453/turk-sinemasinin-100uncu-yilinda-halk-susuz-yaz-dedi. html

Künüçen, H. (2001). Türk Sinemasında Kadının Sunumu Üzerine. Kurgu Dergisi, (18), s.57.

Lindner, A, M., Schulting, Z. (2017). How Movies with a Female Presence Fare with Critics. Socius: Sociological Research for a Dynamic World, 3, (1-6), s.2. Erişim tarihi: 25.08:2018, DOI: 10.1177/2378023117727636

Rughiniș, C., Rughiniș, R. ve B. Humă. (2016). Impromptu Crowd Science and the Mystery of the Bechdel-Wallace Test Movement. Proceedings of the 2016 CHI Conference Extended Abstracts on Human Factors in Computing Systems - CHI EA '16, s. 487-500. Erişim: 27 Ağustos 2018, http://dx.doi. org/10.1145/2851581.2892580

Mičić, Z. (2015). Female Interactions on Film - Beyond the Bechdel test: A quantitative content analysis of same-sex-interactions of top 20 box office films. Stockholm University Department of Media Studies. Yayınlanmamış Yüksek Lisans Tezi. Sweden.

Mulvey, L. (2014). Görsel Zevk ve Anlatı Sineması (E. Soğancılar, Çev.). Ahu Antmen (Ed.) Sanat ve Cinsiyet: Sanat Tarihi ve Feminist Eleştiri. İstanbul, İletişim Yayınları, s.277-299.

Özgüç, A. (1993). 100 Filmde Başlangıcından Günümüze Türk Sineması. Ankara, Bilgi Yayınevi, s.136.

Özön, N. (1963). Sinema Terimleri Sözlüğü. Ankara, Türk Dil Kurumu Yayınları, s.80.

Öztürk, S, R. (2000). Sinemada Kadın Olmak. İstanbul, Alan Yayıncılık, s.69.

Sim, Ş. (2009). Türk Sinema Tarihi'nde İlk Üçleme, Metin Erksan'dan Mülkiyet Üçlemesi: "Yılanların Öcü", "Susuz Yaz", "Kuyu”. Journal of Istanbul Aydın University, 1, (3), s.185.

Sönmez, P. (2010). Türk Sinemasında Sansür ve Metin Erksan Örneği. Selçuk Üniversitesi Sosyal Bilimler Enstitüsü Radyo Televizyon Anabilim Dalı. Yayınlanmamış Yüksek Lisans Tezi, Konya, s.129.

Ulusay, N. (2004). Günümüz Türk Sinemasında "Erkek Filmleri”nin Yükselişi ve Erkeklik Krizi. Toplum ve Bilim, (101), Güz, s.157. 
Uslu, E, G. (2007). Metin Erksan Sinemasında Toplumsal Gerçekçilik ve Bunun Filmlere Yansıması. Selçuk Üniversitesi Sosyal Bilimler Enstitüsü Radyo Televizyon Anabilim Dalı. Yayınlanmamış Yüksek Lisans Tezi, Konya, s.60.

Yalamaç, E. (2011). 2000 Sonrası Türk Sinemasında Kadın Temsilleri. Ege Üniversitesi Sosyal Bilimler Enstitüsü Kadın Çalışmaları Anabilim Dalı. Yayınlanmamış Yüksek Lisans Tezi. İzmir.

Yüksel, S, D. (2010). Sinemada Ulusal Kimliğin Pekiştiricisi Olarak Kadınlar. Selçuk İletişim, 6, (3), s.88. 
